\title{
Bilateral tubo-ovarian abscess and sepsis caused by Salmonella in patients with systemic lupus erythematosus
}

\author{
Selma Guler, ${ }_{1}^{1}$ Hafize Oksuz, ${ }^{2}$ Gozde Yildirim Cetin, ${ }^{3}$ Omer Faruk Kokoglu ${ }^{1}$
}

${ }^{1}$ Department of Infectious Diseases, Faculty of Medicine, Kahramanmaras Sutcu Imam University, Kahramanmaras, Turkey

${ }^{2}$ Department of Anaesthesiology and Reanimation, Faculty of Medicine, Kahramanmaras Sutcu Imam University, Kahramanmaras, Turkey ${ }^{3}$ Faculty of Internal Medicine Division of Rheumatology, Faculty of Medicine,

Kahramanmaras Sutcu Imam University, Kahramanmaras, Turkey

\section{Correspondence to} Dr Selma Guler, selmaguler38@hotmail.com

\section{DESCRIPTION}

A 39-year-old woman was admitted to the emergency department due to abdominal pain. Her history included systemic lupus erythematosus (SLE) and use of immunosuppressive drugs. The patient's general condition was poor with fever and tenderness in the abdomen. Laboratory tests revealed leukopenia $\left(3800 / \mathrm{mm}^{3}\right)$, elevated C reactive protein $(112 \mathrm{mg} / \mathrm{dL})$ and international noramalised ratio (INR 11). In contrast-enhanced CT, bilateral tubo-ovarian abscess was observed sized $86 \times 44$ and $95 \times 88 \mathrm{~mm}$ (figures 1 and 2). The patient was operated after INR level normalised by fresh frozen plasma. She was started on intravenous imipenem/cilastatin therapy empirically. Salmonella spp. was isolated from the blood specimen and abscess material. Salmonella spp. are susceptible to cefepime, ceftazidime trimethoprim-sulfamethoxazole, piperacillin-tazobactam, tigecycline and colistin. But the patient's general condition did not improved, and she died on the fourth day of hospitalisation despite

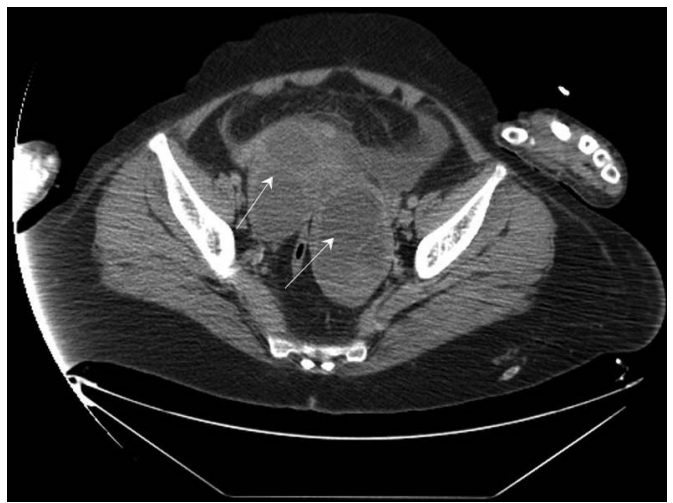

Figure 1 Bilateral tubo-ovarian abscess (arrow).

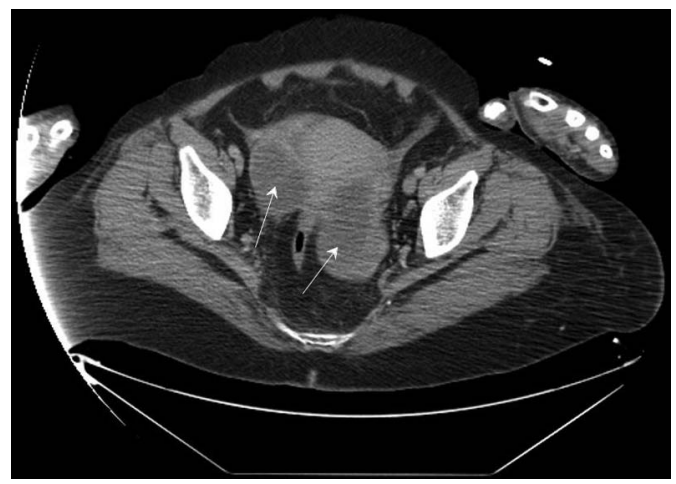

Figure 2 Bilateral tubo-ovarian abscess (arrow). proper treatment. Non-typhoidal salmonellosis is a food-borne infection that occurs in patients throughout the world, especially in immunocompromised patients. The common risk factors include old age, malignancy, diabetes, rheumatological disorders, immunosuppressive therapy and HIV. ${ }^{1}$ Patients with SLE are predisposed to non-typhoidal Salmonella infection with high incidence of bacteraemia and abscess formation. Infection-related mortality rate in patients with connective tissue diseases (CTDs) was 2.1-79\%. The rate of infection-related mortality in SLE is higher than other CTDs, although $83 \%$ of these patients receiving appropriate antimicrobial agent within $72 \mathrm{h.}^{2}{ }^{3}$ Ruptured ovarian cysts, adnexal mass, chronic ectopic pregnancy and malignancy should be considered in the differential diagnosis of tubo-ovarian abscess. ${ }^{4}$

\section{Learning points}

- Non-typhoidal Salmonella (NTS) often results in self-limited infection; however, invasive disease can occur with bacteraemia and subsequent focal infections.

- NTS invasive disease is a rare entity in immunocompetent persons.

- Patients with systemic lupus erythematosus (SLE) can be seen either with NTS bacteraemia and abscess.

- Despite appropriate antibiotic treatment, infection-related mortality rates are high with patients with SLE.

Competing interests None.

Patient consent Obtained.

Provenance and peer review Not commissioned; externally peer reviewed.

\section{REFERENCES}

1 Metan G, Alp E, Esel D, et al. Salmonella enteritidis: an unusual meningitis agent in an adult patient. Mikrobiyol Bul 2005;39:509-12

2 Huang CF, Chen PL, Liu MF, et al. Nontyphoidal Salmonella bacteremia in patients with connective tissue disease. J Microbiol Immunol Infect 2012;45:350-5.

3 Tsao $\mathrm{CH}$, Chen CY, Ou LS, et al. Risk factors of mortality for salmonella infection in systemic lupus erythematosus. J Rheumatol 2002:29:1214-18.

4 Ulukis M, Zekioglu 0. Female genital tuberculosis: a case report. Ege Tip Dergisi 2003;42:205-7. 
Copyright 2013 BMJ Publishing Group. All rights reserved. For permission to reuse any of this content visit http://group.bmj.com/group/rights-licensing/permissions.

BMJ Case Report Fellows may re-use this article for personal use and teaching without any further permission.

Become a Fellow of BMJ Case Reports today and you can:

- Submit as many cases as you like

- Enjoy fast sympathetic peer review and rapid publication of accepted articles

- Access all the published articles

- Re-use any of the published material for personal use and teaching without further permission

For information on Institutional Fellowships contact consortiasales@bmjgroup.com

Visit casereports.bmj.com for more articles like this and to become a Fellow 